\title{
Nutritional care during prenatal and postpartum periods: A report of experiences in a city on São Paulo's coast
}

\author{
A atenção nutricional ao pré-natal \\ e puerpério: relato de experiência \\ em um município do \\ litoral Paulista
}

Anna Sylvia de Campos LAPORTE-PINFILDI ${ }^{1}$

Maria Angélica Tavares de MEDEIROS²

A B S T R A C T

The purpose of this study is to present a report of the experiences of the adoption of the Approach to Nutritional Care during Prenatal and Postpartum Periods, resulting from a partnership between the university and the municipal primary health care system of Santos, SP, Brazil. This approach was developed through joint work plans based on the need to incorporate nutritional care into the prenatal and postpartum care. All stages of design and implementation and the results of this strategy were documented in a field diary. This approach was adopted in two basic health units between 2010 and 2014. The stages of this process were planned in conjunction with health care teams and consisted of putting together interdisciplinary groups for nutrition education during the prenatal period. Interdisciplinary educational group meetings were held focusing on listening to the needs of pregnant women, the provision of prenatal nutritional care, and on the project to monitor the nutritional status of newborns through home visits up to the 15 days of postpartum. The interdisciplinary activities strengthened the bond between the users and the health care team members, contributing to the provision of effective care and promoting integrality. Home visiting contributed to encourage exclusive breastfeeding.

Keywords: Breast feeding. Food and nutrition education. Nutrition, public health. Prenatal care. Primary health care.

\footnotetext{
1 Universidade Federal de São Paulo, Instituto Saúde e Sociedade, Curso de Nutrição. Santos, SP, Brasil.

2 Universidade Federal de São Paulo, Instituto Saúde e Sociedade, Departamento de Políticas Públicas e Saúde Coletiva. Campus Baixada Santista R. Silva Jardim, 136, Vila Matias, 11015020, Santos, SP, Brasil. Correspondência para/Correspondence to: MAT MEDEIROS. E-mail: <angelicamedeiros@gmail.com>.

Article based on the master's thesis of ASCM LAPORTE, entitled "A estratégia de atenção nutricional ao pré-natal e puerpério e a integralidade da atenção materno infantil”. Universidade Federal de São Paulo; 2014.
} 


\section{R E S U M O}

O objetivo deste artigo é relatar a experiência de implantação de Estratégia de Atenção Nutricional ao Pré-natal e Puerpério, resultante de parceria entre universidade e serviço público municipal de atenção básica de Santos (SP). Para tanto, planejou-se conjuntamente o trabalho partindo da necessidade de incorporar a atenção nutricional ao pré-natal e puerpério. Construiu-se Diário de Campo no qual registraram-se a concepção, o processo de elaboração e os resultados desta Estratégia. Desenvolveu-se o trabalho em duas Unidades Básicas de Saúde, no período de 2010 a 2014. As etapas desse processo foram construídas conjuntamente com as equipes de saúde e consistiram na criação de grupo educativo interdisciplinar em nutrição no pré-natal. Desenvolveram-se reuniões educativas interdisciplinares, com foco na escuta às necessidades das gestantes, na implantação do acompanhamento nutricional Pré-natal e no projeto de vigilância nutricional dos recém-nascidos, em visitas domiciliares até o $15^{\circ}$ dia pós-parto. As ações interdisciplinares estreitaram o vínculo entre usuárias e equipes, favorecendo a efetivação da linha do cuidado e fomentando a integralidade. $O$ apoio domiciliar contribuiu para o incentivo ao aleitamento exclusivo.

Palavras-chave: Aleitamento materno. Educação alimentar e nutricional. Nutrição em saúde pública. Cuidado pré-natal. Atenção primária à saúde.

\section{INTRODUCTION}

Prenatal and postpartum care aims to give support to women through pregnancy, contributing to the birth of a healthy infant and to maternal and neonatal well-being. Therefore, a high-quality and humanized prenatal and postpartum care is recommended for a more comprehensive view of the health/disease process that considers the person as a whole and to establish a new basis for a cooperative relationship between the various subjects involved - health care professionals, users, and managers ${ }^{1}$.

According to Ayres², providing health care implies taking into account the experience of the individuals and attentive listening to understand their life plans and the situation they are going through. Listening helps the individual to reflect and focus on a co-responsible care that fosters autonomy.

In Brazil, since the 1980s, there have been several problems affecting prenatal and postpartum care 3 . Despite the increase in prenatal care services and programs ${ }^{4}$, the quality of care provided has been affected, and only some of the pregnant women enrolled benefit from the minimum actions carried out in the program ${ }^{1,5-7}$. This suggests inadequacy of the care provided by those services, not only in terms of the number of prenatal visits, but also in terms of the quality of those visits; this situation is even worse for low-income women'.

The provision of nutritional care is an important part of prenatal care due the importance and influence of pre-pregnancy and pregnancy nutritional status on maternal and newborn health, especially fetal growth and birth weight ${ }^{8}$. According to recommendations of the Brazilian Ministry of Health, prenatal nutritional care should start at the early stages of pregnancy together with educational activities to be undertaken in groups or individually, enabling the exchange of information and knowledge between the women and the health care professionals and facilitating the understanding of the pregnancy process ${ }^{1}$.

Among the strategies with empirical evidence of the effectiveness of breastfeeding promotion are prenatal groups, home visits, mothers' groups, and individual lactation consultations during the prenatal and postpartum periods focusing on health education $n^{9,10}$.

In terms of nutritional care, the promotion of self-care and autonomy are central elements of Educação Alimentar e Nutricional (EAN, Food and Nutrition Education). Therefore, prenatal and postpartum care requires continuous and permanent EAN practices including problemposing and active approaches enabling the dialogue focused on listening to the users needs ${ }^{11,12}$. 
Therefore, the objective of this study is to present a report of the experiences of the adoption of the Approach to Nutritional Care during Prenatal and Postpartum Periods focused on EAN as an element of comprehensive care.

\section{METHODS}

This study consists of a report of the experiences of the adoption of the Approach to Nutritional Care during Prenatal and Postpartum Periods between 2010 and 2014, resulting from a partnership between the university and the Municipal Secretariat of Health of Santos.

The city of Santos has 419,400 inhabitants and an area of $281 \mathrm{~km}^{2}$ with high population density in the insular area $\left(1,492 \text { inhabitants } / \mathrm{km}^{2}\right)^{13}$. Santos is the largest port in Latin America, reason for the city original urban occupation ${ }^{14}$.

With regard to the public health system, low risk prenatal care is provided in 29 Basic Care Units (BCU) spread in four different regions that comprise the insular area of the city: Morros (Hillside area), Zona Noroeste (Northwest Zone), Centro (Downtown), and Orla (Shoreline). There are $9 \mathrm{BCU}$ in the Hillside area, 9 in the Northwest Zone, 5 in the Downtown area, and 6 along the Shoreline.

The partnership between the Universidade Federal de São Paulo campus Baixada Santista (Federal University of São Paulo, Santos Campus Unifesp), and the Municipal Secretariat of Health in the Hillside area was established in 2009 involving education, research, and extension programs. Since then, Social Nutrition Internship programs have been carrying out interdisciplinary actions in conjunction with health care teams, constituting an innovative element of health care activities in the city ${ }^{15}$.

There are Social Nutrition Internship programs in 6 Family Health Units (FHU) in three of the four health regions of Santos: Hillside area, Northwest Zone, and Downtown area. The internships are taken up during the $7^{\text {th }}$ and $8^{\text {th }}$ semesters and are organized in three terms that last three months each, with a total workload of 320 hours, with 30 hours per week. Professors are responsible for supervising the internship program during four hours per week; the remaining hours are supervised by preceptors, health care professionals, and graduate students enrolled in the Program in Social Nutrition Internship.

The Social Nutrition Internship Program activities were carried out and planned in conjunction with the health care teams of the units based on the identification of the health needs of each region.

The report was prepared according to the records that were kept in the field diary during the entire strategy development process. It was written by the interns and the dietitian preceptor and was used as an analysis tool, enabling interpretation and evaluation of the practices, i.e., it included a more comprehensive assessment rather than a simple description of the actions undertaken. A content analysis was carried out including the scanning and skimming reading of the records to understand the meanings of the experience of the adoption of this approach. The material gathered in each internship term was passed on to the next interns to ensure the actions would be continued. Moreover, the diary records supported the procedural evaluation of the internship by the professors supervising the internship program ${ }^{15}$.

In the present study, it was assumed that the actions would be based on the principles of food and nutrition education, which aims to promote autonomy and the voluntary adoption of healthy eating practices using strategies and problem-posing educational resources that would allow the participant pregnant women to reflect upon their dietary practices and find ways to improve their eating habits. Among these features, is the use of group dynamics, such as "monte seu prato" (make your own plate), a practical demonstration of the amount of sodium present in their daily diet, and ingredient 
substitution tips to make the recipes brought by them healthier among others. In all of the actions, the interactions and meanings of their eating behavior were taken into accout instead of normative and prescriptive actions ${ }^{11,16}$.

This study was approved by the Research Ethics Committee of the Universidade Federal de São Paulo (Unifesp, Federal University of São Paulo), Protocol n 32900.

\section{RESULTS AND DISCUSSION}

This strategy used was implemented in two basic health units in the Hillside area of Santos (SP), from 2010 to 2014, during the internship terms. The work process for the development of the Approach to Nutritional Care during Prenatal and Postpartum Periods consisted of two stages.

The first stage was the proposal of forming an interdisciplinary group for nutrition education that would evaluate and monitor the participant's nutritional status and their dietary practices during pregnancy. The group was also responsible for the implementation of actions that promoted food and nutrition education during pregnancy aiming to achieve better health outcomes for the mother-infant dyad and encourage Exclusive Breast Feeding (EBF) in the first six months.

Before forming the group, meetings were held between the university and the health care units over a three-month period in order to identify the needs to be addressed in the educational practices and to develop integrated work strategies. Challenges related to the participation of the pregnant women and health care teams in the program activities were also discussed. Examples of these challenges are time conflicts between prenatal appointments and group activities and the lack of team members' recognition of the importance of educational activities.

The following professionals participated in the planning process: nutrition interns, preceptor dietitian, unit manager, and health care team members (nurses, gynecologists, pediatricians, community health agents, and nurse technicians). The action plan, an adequate physical space, the update of medical records system records, and the joint work between team members and the nutrition interns were discussed and defined. Moreover, a protocol (Annex 1) was developed containing socioeconomic status and past pregnancy and health history to characterize the population served and support the planning of educational activities.

Educational activities were carried out in weekly group meetings on the day of prenatal visits. Four group meetings were held monthly during the course of nine months of pregnancy, totaling an average of 36 meetings per year. Each group was composed of approximately 10 pregnant women who were asked to arrive an hour before their doctor's appointment to participate in the group meetings, which lasted 40-60 minutes. The groups also included the following professionals: dietitians, nurses and nursing assistants, Community Health Agents (CHA), social workers, and nutrition interns. All of these professionals and the students participated in the group meetings every week, expect for the nurses and social workers whose frequency of participation varied.

Aiming at a closer relationship between the professionals and encouraging the participation of pregnant women in this educational activity, nutrition interns and nursing assistants carried out a weekly evaluation of the women in each group half an hour before their scheduled prenatal visit, which consisted of measurements of weight, height, and blood pressure, and questions about their health and socioeconomic status. Those data were analyzed and entered into their maternity record card. The Monitoring of Prenatal Nutritional Status procedure was adopted for the first time in those health care units, which strengthened the bonds and increased participation of the women in the group meetings.

A preliminary evaluation carried out during the first stage of implementation of this strategy ${ }^{17}$ revealed that a total of 48 pregnant women were 
monitored through the educational groups; 35\% of those women had started the prenatal care during the first trimester of pregnancy. As for their nutritional status, most of them were eutrophic (45\%), $25 \%$ were overweight, and $66.6 \%$ carried the pregnancy to term.

The evaluation and the diagnosis of the nutritional status through anthropometric measurements are recommended for an effective nutritional monitoring of pregnant women due to its importance for the prevention of perinatal morbidity and mortality, prognosis of fetal development, and promotion of women's health ${ }^{18}$. Health problems during pregnancy related to pregestational weight gain have been reported in the literature, especially hypertensive disorders of pregnancy and low birth weight ${ }^{19-20}$. These findings demonstrate the importance of monitoring weight gain during the prenatal period and the identification of pregnant women at nutritional risk.

Studies addressing the quality of nutritional care during the prenatal period reveal that the weight and blood pressure measurements are routine procedures during prenatal visits ${ }^{21,22}$. However, other studies have reported the lack of height measurements, provision of educational activities, diet guidance, and evaluation of Body Mass Index (BMI)/gestational age $7,21,23-25$.

In a recent study, Niquini et al. ${ }^{26}$ evaluated the nutritional care in the prenatal period in 7 FHUs in Rio de Janeiro, Brazil. In terms of the quality of the nutritional care provided, the authors found that only $45.0 \%$ of the pregnant women's maternity record card had updated information', including the BMI/gestational age curve, and $90.7 \%$ of the maternity cards did not have any $\mathrm{BMI} /$ gestational age curve updates. Pregestational weight and height records were present in $65.9 \%$ and $57.7 \%$ of the maternity cards, respectively. The authors also pointed out that less than $40.0 \%$ of the pregnant women received specific nutritional counseling on diet, weight gain, and use of supplementation during pregnancy ${ }^{26}$.
The absence of information on height was also reported in other studies ${ }^{21,23,24}$, suggesting the disregard of the nutritional monitoring of pregnant women hindering the evaluation of the initial nutritional status, the monitoring of weight gain during pregnancy, and the updates on the $\mathrm{BMI} /$ gestational age curve. It is important to mention that those studies did not consider the measurement of height as part of the essential procedures of nutritional care during the prenatal period.

In contrast, the actions undertaken with the implementation of the strategy discussed in the present study contributed to the effective provision of the nutritional care during the prenatal period. This could be observed by the adoption of anthropometric evaluation as an essential procedure, including weight, height, and pregestational weight measurements, enabling nutritional monitoring, maternity record card updates, and the identification of risks. These procedures were not part of the routine prenatal care in the health care unit investigated before the implementation of this strategy.

Like the investigation carried out by the authors of the present study, Siqueira ${ }^{27}$ investigated the prenatal care provided in another BCU in the city of Santos and found that of the 366 medical records evaluated only one had an updated BMI/gestational age curve, which was actually only partially updated. The author believes that this finding is due to the lack of nutritional status assessment and the health professionals' disregard for it, suggesting that they were not aware of the clinical value of this information.

In another study by the authors of the present study, carried out during the implementation of the strategy in question ${ }^{28}$, maternal and infant health risks and poor monitoring of prenatal and postpartum periods and infant's health were identified, reinforcing the need to improve the care provided to this population, according to guidelines issued by the "Política Nacional de Alimentação e Nutrição" 29 . 
The educational actions carried out as part of the strategy investigated in this study were focused on listening, the establishment of trust based relationships, and the acknowledgment of the pregnant women needs. Therefore, workshops and rounds of conversation were held in a private room, where the participants could share their experiences, strengthening the bonds between pregnant women and the health care teams. Based on the field diary records, it was observed that these women felt comfortable sharing their experiences and feelings with each other. Primiparous women talked to multiparous women expressing their doubts and fears related to the arrival of the baby, recognizing their knowledge and experiences of previous pregnancies. There were moments of emotional ventilation and confessions that strengthened the bonds between the participants.

The activities were designed according to the demand observed in the initial diagnosis. Some of the topics addressed were: healthy eating, weight gain, sodium intake, hydration, supplements, baby care, rights, and breastfeeding, following the recommendations of the "Manual Técnico de Pré-natal e Puerpério do Ministério da Saúde" (Prenatal and Postpartum Technical Manual by the Ministry of Health) ${ }^{1}$.

According to Freire ${ }^{30}, "$ "...to teach is not to transfer knowledge but to create the possibilities for the production or construction of knowledge" The educational group activities were focused on encouraging talking and experience exchange, as well as on fostering a trust based relationship between the group members. The professionals and interns involved acted as facilitators, avoiding the use of the lecture-style during the meetings, which is unproductive and that overshadows the underlying issues that may be more relevant to the participants than a pre-established script.

Other actions resulting from forming the interdisciplinary group for nutrition education were: a bulletin board was collectively (health care teams/women) made with proper identification of the participant women and pictures of their babies, and the newborn health surveillance project was developed.

The second stage of the development of the Approach to Nutritional Care during Prenatal and Postpartum Periods was integrated with the prenatal groups. In other words, the bonding established in the educational groups led to the development of the newborn health surveillance project, which emerged to enable continuity of care and consisted of Home Visits (HV) during 15 days of postpartum. This project was focused on encouraging Exclusive Breastfeeding (EBF) for up to six months and on counseling techniques, according to the "Dez Passos para o Sucesso do Aleitamento Materno" ("Ten Steps to Successful breastfeeding") ${ }^{31}$. Therefore, a protocol (Annex 2) containing sociodemographic data and information about birth, birth weight, household hygiene, breastfeeding techniques, mother's health and diet, and identification of potential risks to the health of newborns was used. In conjunction with the health care team, all births occurred in that region were mapped for the planning of home visits to all participants of the prenatal care program.

During the home visits, the nursing mothers felt comfortable talking about breastfeeding difficulties, allowing observation of the practice. Thus, it was possible to identify problems related to the care of the newborns, such as challenges associated with breastfeeding techniques or early introduction of complementary foods, and to identify the most common difficulties encountered by the mothers.

The interns, the dietitian preceptor, and the community health agent were present in every home visit. The visits included counseling on breast hygiene, proper breastfeeding latch, complete emptying of the breast, importance of exclusive breastfeeding for six months, and instructions to avoid the use of pacifiers, bottles, and bottle nipples. The mothers were also encouraged to have a postpartum check-up in the health care unit. When problems related to exclusive breastfeeding and its techniques were identified, another home visit was scheduled and 
these cases were then discussed with the health care team aiming at a more systematic and integrated monitoring.

Preliminary results ${ }^{17}$ showed that 42 out of the 48 pregnant women in the groups received home visits until the $15^{\text {th }}$ day of child birth. Their average age was 27 years (standard deviation 7.7); the majority $(83.3 \%)$ of the women were exclusively breastfeeding their babies, and $16.7 \%$ were following the predominant breastfeeding pattern. However, $40.5 \%$ of these women reported not having received any counseling on breastfeeding after delivery. Breastfeeding difficulties were reported by $21.4 \%$ of the mothers, especially problems related to nipple soreness or trauma, and during breastfeeding observation, $26.2 \%$ showed inadequate breastfeeding techniques, especially not emptying the breasts effectively during breastfeeding. These results indicated ineffective actions to encourage breastfeeding, mainly during the first days of the baby's life in maternity wards, reinforcing the importance of EAN actions that address breastfeeding based on counseling during the prenatal and postpartum periods.

In terms of comprehensive care, home visits are considered an important health protection measure, especially if carried out frequently, seeking to strengthen the bond between pregnant women/nursing mothers and the health care unit, with comprehensive approach including the woman and her family in their social context ${ }^{1,32}$. For an effective breastfeeding support, the first home visit should occur within the 14 days of postpartum because this is a critical period for the adoption of this practice due to common breastfeeding challenges. On the other hand, this is a period that involves the need to absorb a great deal of new information, and therefore it is a window of opportunity to encourage breastfeeding and to establish a close relationship between the mother and the health care professionals ${ }^{33}$.

In a study based on interviews with pregnant women and health care professionals, Zampieri \& Erdmann ${ }^{34}$, reported that educational practices and home visits are considered humanized actions by pregnant women.
According to the women interviewed, they increase knowledge, support decisions, prepare for childbirth, and contribute to claim their rights for care. Analyzing these issues in terms of comprehensive care, nutritional care should not be based only on technical and scientific knowledge. Dietary counseling can be defined as a kind of dialogic support, aimed at the individuals' autonomy in decision-making, considering their organic, emotional, and sociocultural characteristics ${ }^{35}$.

Educação Alimentar e Nutricional (EAN, Food and Nutrition Education) has been the subject of much debate, and some actions carried out in the country have been recognized as ineffective. Analyzing recent studies on educational programs, Santos et al. ${ }^{24}$ observed the predominance of lectures and courses as intervention model programs. Thus, in the approach discussed in this study, the EAN practices were developed aiming at the women's autonomy to adopt healthy eating habits, considering their living conditions and their cultural background. Based on these goals, the group dynamics and rounds of conversation were focused on experience exchange between the participant women during pregnancy and breastfeeding. For example, the 'make your own plate' dynamics stimulated reflections about their own eating habits.

According to the literature on the main prenatal care characteristics and those observed in the health care services of Santos, it can be said that the routine prenatal visits in primary health care are focused on procedures only, without offering opportunities for knowledge and experience sharing ${ }^{28}$. Besides good quality prenatal care, humanized care is the first step towards a healthy birth and a healthy and safe pregnancy ${ }^{34}$. Accordingly, it is worth highlighting the important role of nutritional education as a way to promote individuals' autonomy and comprehensive care ${ }^{28}$.

Despite the importance of the report of the experiences of the adoption of the Approach to Nutritional Care during Prenatal and Postpartum Periods, in order to adequately understand the theory and level of the adoption of this 
approach $^{36}$, it is necessary to evaluate the results of this intervention. Thus, further studies are suggested to investigate the impact of these actions on the promotion of maternal and infant health and to identify problems and propose solutions for the improvement of food and nutrition policies in primary health care.

Although this experience proved to be successful, it is important to point out its limitations and challenges, such as the difficulty of some professionals in recognizing the role of nutritional care as part of routine prenatal care, which has long been limited to medical appointments only. As previously mentioned, the planning meetings were very important to raise awareness among the health care team, but the participation of some professionals was irregular affecting communications and leading to, in some occasions, differences in practices between dietitians and doctors. Another limiting factor is that the frequency of the group meetings became irregular during the university vacation periods, indicating low level of involvement of the health care team in this process.

To combat these limitations, we recommend the inclusion of training workshops with the health care professionals during the process planning to enable sharing knowledge and Food and Nutrition Education actions and the use of theoretical frameworks to provide guidance to those involved.

On the other hand, from the interns' perception, this experience increased their level of commitment to the services provided and to pregnant and postpartum (puerpera) women. Moreover, according to them, it also promoted the teaching-learning process. The health care professionals involved believe that the involvement of the university, including professors, students, and the internship preceptor, contributed to improve the nutritional care offered in these health care units and to increase knowledge about food and nutrition. These findings demonstrate the importance of this experience, reaffirming the role of the partnership between university and health care service.

\section{CONCLUSION}

The partnership between the university and the health care system promoted closer attention to the need for monitoring during the prenatal period, and the interdisciplinary actions strengthened the bonds between pregnant women/mothers and health care teams, paving the way for effective care promoting integrality. The use of the field diary proved to be important to systematize the records and for activity evaluations. Home care support during the postpartum period contributed to encourage exclusive breastfeeding. Further studies are needed to assess the impact of the actions of the Approach to Nutritional Care during Prenatal and Postpartum Periods and to investigate the implementation of this project in other primary health care units, improving the quality of health care provided in Santos.

\section{CONTRIBUTORS}

ASC LAPORTE-PINFILDI contributed to the project conception and design, and data analysis and the writing of the manuscript. MAT MEDEIROS contributed to the projetct concpetion and design, and data analysis and the final review of the manuscript.

\section{REFERE N CES}

1. Brasil. Ministério da Saúde. Secretaria de Atenção à Saúde. Atenção ao pré-natal de baixo risco. Brasília: MS; 2012 [Acesso 2014 ago 2]. p.318. Disponível em: http://bvsms.saude.gov.br/bvs/ publicacoes/cadernos_atencao_basica_32_ prenatal.pdf

2. Ayres JRC. Cuidado e humanização das práticas em saúde. In: Deslandes S, editor. Humanização dos cuidados em saúde: conceitos, dilemas e práticas. Rio de Janeiro: Fiocruz; 2006. p.49-83.

3. Serruya SJ, Cecatti JG, Lago TG. O programa de humanização no pré-natal e nascimento do Ministério da Saúde no Brasil: resultados iniciais. Cad Saúde Pública. 2004 [Acesso 2013 jun 14]; 20(5):1281-9. Disponível em: http://www.scielo.br/ scielo.php?script=sci_arttext \&pid=S0102-31 $1 \times 2004000500022 \&|n g=p t \& n r m=i s o \& t| n g=p t$ 
4. Brasil. Ministério da Saúde. Pesquisa nacional de demografia e saúde da criança e da mulher: PNDS 2006. São Paulo: Cebrap; 2009.

5. Domingues RMSM, Hartz ZMA, Dias MAB, Leal MC. Avaliação da adequação da assistência pré-natal na rede SUS do município do Rio de Janeiro, Brasil. Cad Saúde Pública; 2012 [acesso 2015 dez 16]; 28(3):425-37. Disponível em: http://www.scielo.br/ scielo.php?script=sci_arttext\&pid=S0102-31 1X2012000300003\&lng=en\&nrm=iso\&tlng=pt

6. Gonçalves CV, Cesar JA, Mendoza-Sassi RA. Quality and equity in prenatal care: A population- based study in Southern Brazil. Cad Saúde Pública. 2009; 25(11):2507-16. http://dx.doi.org/10.1590/S0102-3 11X2009001100020

7. Parada CMGDL. Avaliação da assistência pré-natal e puerperal desenvolvidas em região do interior do Estado de São Paulo em 2005. Rev Bras Saúde Matern Infant. 2008; 8(1):113-24. http://dx.doi. org/10.1590/\$1519-38292008000100013

8. Zadik Z. Maternal nutrition, fetal weight, body composition and disease in later life. J Endocrinol Invest. 2003; 26(9):941-5. http://dx.doi.org/10. 1007/BF03345248

9. Oliveira MIC, Camacho LAB, Souza IEO. Promoção, proteção e apoio à amamentação na atenção primária à saúde no estado do Rio de Janeiro, Brasil: uma política. Cad Saúde Pública. 2005 [Acesso 2014 out 28]; 21(6):1901-10. Disponível em: http:// www.scielo.br/scielo.php?script=sci_arttext\& pid=S0102-311X2005000600040\&lng=pt\&nrm= iso\&tlng=pt

10. Oliveira MIC, Camacho LAB, Tedstone AE. Extending breastfeeding duration through primary Care: A Systematic Review of Prenatal and Postnatal interventions. J Hum Lact. 2001; 17(4):326-43.

11. Brasil. Ministério do Desenvolvimento Social e Combate à Fome. Marco de referência de educação alimentar e nutricional para políticas públicas. Brasília: MDS; 2012.

12. Santos LAS. O fazer educação alimentar e nutricional: algumas contribuições para reflexão. Ciên Saúde Coletiva. 2012; 17(2)453-62.

13. Instituto Brasileiro de Geografia e Estatística. Ministério do planejamento orçamento e gestão cidades Santos - Censo. Rio de Janeiro: IBGE; 2010 [acesso 2013 abr 4]. Disponível em: http://www. ibge.gov.br/cidadesat/link. php?codmun=354850

14. Campos FCB, Moreira MIB, Paula YA, Paulo LF, Medeiros MAT. O terreiro lá de casa: reconhecimento de bens culturais e bons encontros na comunidade. Rev Diálogos. 2010 [Acesso 2013 jun 2]; 14:53-62. Disponível em: http://portalrevistas. ucb.br/index.php/RDL/article/viewArticle/2928
15. Medeiros MAT, Braga-Campos FC, Moreira MIB. A integralidade como eixo da formação em proposta interdisciplinar: estágios de nutrição e psicologia no campo da saúde coletiva. Rev Nutr. 2014; 27(6):785-98. http://dx.doi.org/10.159/1415-52 732014000600012

16. Medeiros MAT. Desafios do campo da alimentação e nutrição na Atenção Básica. Rio de Janeiro: Guanabara Koogan; 2011. p.173-80.

17. Laporte-Pinfildi ASC. A Estratégia de atenção nutricional ao pré-natal e puerpério e a integralidade da atenção materno infantil [mestrado]. Universidade Federal de São Paulo; 2014.

18. Coelho KS, Souza Al, Batista Filho M. Avaliação antropométrica do estado nutricional da gestante: visão retrospectiva e prospectiva. Rev Bras Saúde Matern Infant. 2002; 2(1):57-61.

19. Yekta Z, Ayatollahi H, Porali R, Farzin A. The effect of pre-pregnancy body mass index and gestational weight gain on pregnancy outcomes in urban care settings in Urmia-Iran. BMC Pregnancy Childbirth. 2006 [Acesso 2014 mar 10]; (1):15. Disponível em: http://www.biomedcentral.com/1471-2393/6/15

20. Bodnar LM, Catov JM, Klebanoff M A, Ness RB, Roberts JM. Prepregnancy body mass index and the occurrence of severe hypertensive disorders of pregnancy. Epidemiology. 2007; 18(2):234-9.

21. Carvalho DS, Novaes HMD. Avaliação da implantação de programa de atenção pré-natal no município de Curitiba, Paraná, Brasil: estudo em coorte de primigestas. Cad Saúde Pública. 2004; 20(Supl. 2):\$220-30.

22. Coutinho T, Teixeira MTB, Dain S, Sayd JD, Coutinho LM. Adequação do processo de assistência pré-natal entre as usuárias do Sistema Único de Saúde em Juiz de Fora-MG. Rev Bras Ginecol Obs. 2003; 25(10):717-24.

23. Costa GD, Cotta RMM, Reis JR, Siqueira-Batista R, Gomes AP, Franceschini SDCC. Avaliação do cuidado à saúde da gestante no contexto do Programa Saúde da Família. Ciên Saúde Colet. 2009; 14:1347-57.

24. Santos LA, Mamede FV, Clapis MJ, Bernardi JVB. Nutritional guidance during prenatal care in public health services in Ribeirão Preto: Discourse and care practice. Rev Lat Am Enfermagem. 2006; 14(5):688-94.

25. Trevisan MDR, Lorenzi DRS, Araújo NM, Ésber K. Perfil da assistência pré-natal entre usuárias do Sistema Único de Saúde em Caxias do Sul. Rev Bras Ginecol e Obs. 2002; 24(5):293-9.

26. Niquini RP, Bittencourt SA, Lacerda EMDA, Saunders C, Leal MDC. Avaliação do processo da assistência nutricional no pré-natal em sete unidades de saúde 
da família do município do Rio de Janeiro. Ciên Saúde Colet. 2012; 17(10):2805-16.

27. Siqueira CVC. Assistência Pré-natal em uma Unidade Básica de Saúde do Município de Santos [mestrado]. São Paulo: Universidade de São Paulo 2011.

28. Laporte-Pinfildi ASC, Zangirolani L, Spina N, Martins $P$, Medeiros M. Atenção nutricional no pré-natal e no puerpério: percepção dos gestores da Atenção Básica à Saúde. Rev Nutr. 2016; 29(1):109-23. http:// dx.doi.org/10.159/1678-98652016000100011

29. Brasil. Ministério da Saúde. Secretaria de Atenção à Saúde. Política Nacional de Alimentação e Nutrição. Brasília: MS; 2012.

30. Freire P. Pedagogia da autonomia: saberes necessários à prática educativa. $43^{\circ}$ ed. São Paulo: Paz e Terra; 2011.

31. Brasil. Ministério da Saúde. Secretaria de Atenção à Saúde. Dez passos para uma alimentação saudável. Brasilia: MS; 2010. p.1-76.

32. Albuquerque $A B B$, Bosi MLM. Visita domiciliar no âmbito da estratégia saúde da família: percepções de usuários no município de Fortaleza, Ceará, Brasil. Cad Saúde Pública. 2009; 25(5):1103-12.

33. Giugliani ERJ. O aleitamento materno na prática clínica breastfeeding in clinical practice. J Pediatr. 2000; [Acesso 2014 jul 25]; 76(3):238-52. Disponível em: http://www.ncbi.nlm.nih.gov/pubmed/ 14676902

34. Zampieri MFM, Erdmann AL. Cuidado humanizado no pré-natal: um olhar para além das divergências e convergências. Rev Bras Saúde Matern Infant. 2010; 10(3):359-67.

35. Bueno LGDS, Teruya KM. Aconselhamento em amamentação e sua prática J Pediatr. 2004; 80(5):126-30.

36. Broussele A, Champagne F, Contrandipoulos A, Hartz Z. Avaliação: conceitos e métodos. Rio de Janeiro: Fiocruz; 2011.

Received: May 1, 2016

Final version: August 12, 2016

Approved: September 22, 2016 


\section{Annex 1}

SOCIAL NUTRITION INTERNSHIP PROGRAM - HILLSIDE AREA

Date: I

Medical Record

\section{User's Identification}

Name: // Birth date: // Age: years

Marital Status: Receive financial assistance from companion/spouse or family members?

Pregnancies: Deliveries: Type of delivery: Vaginal deliveries:

Abortions/miscarriages: Cesarean deliveries:

Date of last menstrual period (LMP): Estimated date of delivery (EDD):

Gestational age:

Reason for the appointment/Patient profile:

\section{Lifestyle}

- Tabagism: ( ) Yes ( ) No Number of cigarettes/day: // Alcohol consumption: ( ) Yes ( ) No // Frequency: Quantity::

- Physical activity ( ) Yes ( ) No // Type: Duration: Freq./week:

- Hours of sleep // Frequent partygoer:

- Place of meals: // Eat alone ( ) Eat in the company of others ( ) // Time of the day when feel most hungry:

- Who prepares the meals? // Who shops for food?

- Food preferences:

- Food aversions:

- Bowel habits: Urinary habits

- Water intake:

\section{Socioeconomic Data}

- Educational Level: // Student: ( ) Yes ( ) No

- Work outside the home? ( ) Yes ( ) No Formal work? ( ) Yes ( ) No // Occupation:

- When will return to work after giving birth: months. Who will take care of the baby?

- Education level of household head: years. Occupation of household head: . Formal work? ( ) Yes ( ) No

- Own a house ( ) Rent a house ( ) // Basic sanitation: // Number of rooms: Garbage collection: times/week

- Number of persons in the household: adults children // Relationship to you:

- Family relationships (psychosocial aspects and behavior dynamics: calm persons; tense persons, communication pattern, difficulties)

\section{Family Health history (diseases):}

Hypertension: Yes ( ) No ( ) Who?

Dyslipidemia: Yes ( ) No( ) Who?

Diabetes: $\quad$ Yes ( ) No( ) Who?

Obesity: Yes ( ) No( ) Who?

Cancer: $\quad$ Yes ( ) No( ) Who?

Heart diseases: Yes ( ) No( ) Who? 
Personal health record:

- Presence of: ( ) nausea

( ) vomiting

( ) heartburn

( ) others

- Treatment with the use of medications/supplements

- Laboratory tests:

Access to Family Food and Nutrition Programs:

1. Beneficiary of the Programa Bolsa Família (Family Allowance Program)? ( ) Yes Number of beneficiaries: children adults ( ) No ( ) do not know

2. Beneficiary of the Programa Vivaleite (Milk Program) ( ) Yes adults ( ) no ( ) do not know

Number of beneficiaries: children

3. Beneficiary of other types of cash transfer or assistance programs? ( ) Yes ( ) vale refeição (meal ticket)

\section{Anthropometric Data}

Pre-gestational weight: Kg Height: cm Pre-gestational BMI: $\mathrm{Kg} / \mathrm{m}^{2}$ Initial Nutritional Status: (IOM,1990)

Pregnancy weight gain recommendation: from to $\mathrm{Kg}$

Atalah Classification criteria:

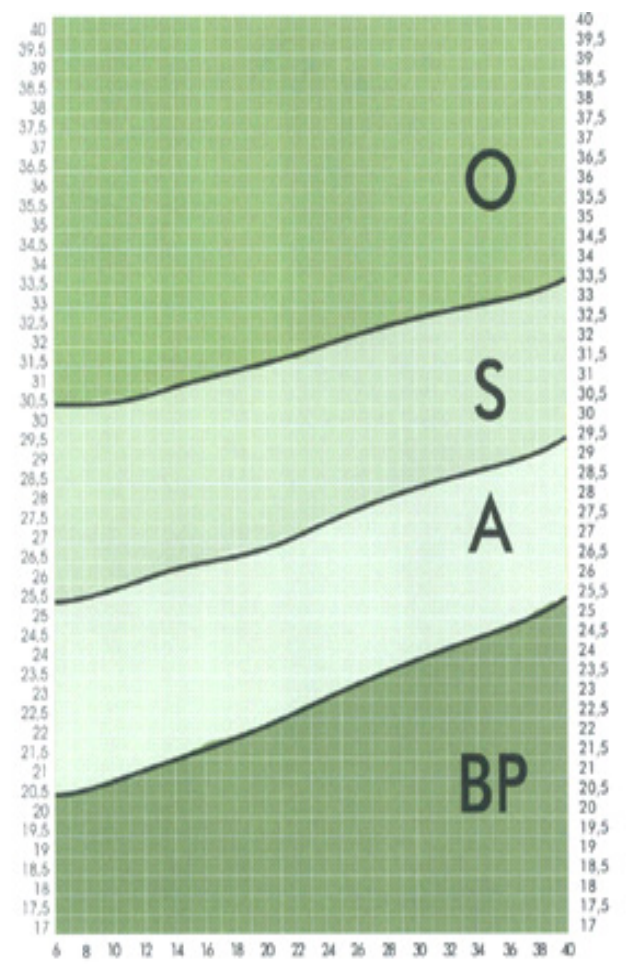

Nutritional Diagnostic Hypothesis:

Daily Eating Habit (Time and quantities) 
Frequency of Consumption (daily, weekly and/or monthly):

$\begin{array}{llll}\text { Read meat } & \text { Bean } & \text { Olive oil } & \text { Tea } \\ \text { White meat } & \text { Vegetable } & \text { Sauce } & \text { Coffee } \\ \text { Pork meat } & \text { Leaf veg. } & \text { Ind.condiments } & \text { Sweetener } \\ \text { Fish } & \text { Fruit } & \text { Mayonnaise } & \text { Home made desserts } \\ \text { Hard-boil./fri. Eggs Coz./Frito } & \text { Pasta/pastries } & \text { Encased meats } & \text { Indust. desserts and } \\ \text { Whole/skim milk } & \text { Margarine } & \text { Canned food } & \text { Sweets/candies } \\ \text { Cheese } & \text { Butter } & \text { Fruit juice } & \text { Cookies/crackers } \\ \text { Yogurt } & \text { Lard } & \text { Soft drinks } & \\ \text { Rice } & \text { Fried foods } & \text { Alcoh. Beverage } & \end{array}$

Monthly Consumption (verify whether oil is reused):

Food Consumption
Oil
Salt
Sugar

Per capta (g)

Ideal Consumption per capita

$30 \mathrm{~mL}$

$4-6 \mathrm{~g}$

$20-30 \mathrm{~g}$

TEE:

//

TEV: ]

Evaluation (psychosocial and dietetic):

Nutritional Plan:

Scheduled return appointment 
Annex 2

SOCIAL NUTRITION INTERNSHIP PROGRAM- HILLSIDE AREA

Date:___ _ _ _ _ _ Family Data:

\section{I - Puerpera Identification}

Name: Age: years.

Address:

Father's name: Complement: Phone:

Pregnancies: Deliveries: Type of delivery: Vaginal deliveries: Abortions/miscarriages:

Cesarean deliveries:

\section{II - Socioeconomic Data}

Mother's education level: years. Student: ( ) Yes ( ) No Mother works outside the home? ( ) Yes ( ) No. Formal Work? ( ) Yes ( ) No

When will return to work after giving birth: months. Who will take care of the baby?

Father's education level: years. Student: ( ) Yes ( ) No

Occupation of household head: Formal Work? ( ) Yes ( ) No

Number of persons in the household: How many work?

Own a house: ( ) Yes ( ) No. Basic sanitation: ( ) Yes ( ) No. Garbage collection times/week

\section{III - Household Hygiene (interviewer observations):}

Clean:

Clean backyard:

Clean kitchen:

Presence of flies and other insects:

Proper ventilation:

Natural light:

Moisture in walls:

Finished floor:

Animals inside the house:

Type:
( ) Yes ( ) no

( ) Yes ( ) no

( ) Yes ( ) no

( ) Yes ( ) no

( ) Yes ( ) no

( ) Yes ( ) no

( ) Yes ( ) no

( ) Yes ( ) no

( ) Yes ( ) no

\section{IV - Newborn Data (check vaccination record card):}

Name: Birth date

Birth weight: g. Lenght: $\mathrm{cm}$. Head circumference: $\mathrm{cm}$.

Chest circumference: $\mathrm{cm}$. Apgar score at the $1^{\text {st }} \mathrm{min}$ : at the $5^{\text {th }} \min$ :

Delivery: ( ) Vaginal ( ) Cesarean ( ) Forceps

Place of delivery:

Fetal Age:

( ) $<22$ weeks ( ) 22 to 27 weeks ( ) 28 to 31 weeks ( ) 32 to 36 weeks

( ) 37 to 41 weeks ( ) 42 weeks and over ( ) no answer.

Pregnancy Complications: ( ) Diabetes ( ) Hypertension ( ) Other: Weight gain during pregnancy (ask about pregestational data: weight and length):

Received prenatal care: ( ) yes ( ) no Place: number of prenatal visits:

Difficulties encountered by the mother:

Who helps taking care of the baby:

Good personal hygiene: ( ) yes ( ) no. If not, describe the problem:

Give baby daily baths: ( ) yes ( ) no Who bathes the baby:

Umbilical cord stump: Baby is dressed adequately according to the weather: ( ) yes ( ) no 


\section{V - Breastfeeding data:}

Breastfeeding patterns:

Baby formula or others: ( ) Yes ( ) No

Type: Started at: days

Reason:

Dilute baby's formula: ( ) Yes ( ) No

Proportions of powdered formula to water:

Introduced:

Plain water: ( ) Yes ( ) No

Sugar water: ( ) Yes ( ) No

Honey: ( ) Yes ( ) No Tea: ( ) Yes ( ) No Type:

Reason:

Small size bottle/regular size bottle: ( ) Yes ( ) No. Pacifier: ( ) Yes ( ) No. When:

Received instructions on breastfeeding in the place of birth? ( ) Yes ( ) No

Instructions given:

\section{Breastfeeding Techniques (interviewer observations)}

Proper latch-on involving the areola: ( ) Yes ( ) No. Empty the breasts: ( ) Yes ( ) No

Correct breastfeeding position: ( ) Yes ( ) No. Interval between feedings:

Nipple trauma: ( ) Yes ( ) No. Use of ointment: ( ) Yes ( ) No

Mother diet:

Mother water intake:

\section{VI - Health Care:}

The infant will receive care at: ( ) BCU （）FHU ( ) Health plan assistance ( ) Other

Vaccines: BCG ( ) Yes ( ) No. Hepatitis ( ) Yes ( ) No.

\section{VII - Problems identified and instructions given to the mothers:}

Postpartum check-up at the BCU/FHU (verify):

Date:

Home visit support team: (identify all) 
